\title{
山崎断層西端部地域の活構造
}

\author{
京都大学理学部地質学鉱物学教室*1 桂 郁 雄 - 山田悦 久・西 村 進 \\ 九州大学工学部資源工学教室*2 茂 木 透 \\ 大谷大学文学部*3 西 田 潤 一 \\ 京都大学防災研究所鳥取微小地震観測所 ${ }^{* 4}$ 中 尾 節 郎
}

\section{Tectonic Zones at the Western-end Region of the Yamasaki Fault}

\section{Ikuo Katsura, Yoshihisa Yamada, Susumu Nishimura}

Department of Geology and Mineralogy, Faculty of Science, Kyoto University,

Kitashirakawa-Oiwake-cho, Sakyo-ku, Kyoto-shi, Kyoto-fu 606, Japan

\section{Tohru MogI}

Department of Mining, Faculty of Engineering, Kyushu University, Hakozaki 6-10-1, Higashi-ku, Fukuoka-shi, Fukuoka-ken 812, Japan

\section{Jun'ichi NishidA}

The Faculty of Literature, Otani University, Koyama-Kazusa-cho, Kita-ku, Kyoto-shi, Kyoto-fu 603, Japan

\section{and Setsuro NAKaO}

Tottori Microearthquake Observatory, Disaster Prevention Research Institute, Kyoto University, Engoji-Hamada 257-2, Tottori-shi, Tottori-ken 680, Japan

(Received August 3, 1989; Accepted September 22, 1989)

Geophysical surveys were carried out to trace the fracture zones in the Awakura and the Ute areas, the northeastern part of Okayama Prefecture, which borders on Tottori and Hyogo Prefectures. The Yamasaki fault terminates in these areas. The methods employed were ELF-magnetotelluric sounding and $\gamma$-ray survey. The trends of low resistivity zones were deduced from the principal axis directions of impedance tensor. The peak positions of $\gamma$-ray count rate suggest the location of fault lines at the surface layer. The traces of faults were estimated from the results of the surveys combining with the topographic lineaments. The estimated traces show that the Yamasaki fault sprays westward into several branches. A north-south striking fracture, which is tentatively named the Ute fault, is also estimated along the west side of the Kajinami River in Katsuta-cho. The northern extension of the Ute fault is considered to be linked with the linear array of epicenters between Tottori and Chizu. The Ute fault is a candidate for the boundary of tectonic blocks dividing the Chugoku and the Kinki districts.

\section{§1。はじめに}

潜在活断層も含めて活断層の分布を詳しく調べること により, 近畿地方北西部地域においては, 地款, 少なく ともその上部は, 主要な横ずれ型活断層により境された

*1 于606 京都市左京区北白川追分町

$*^{2}$ 于 812 福岡市東区箱崎 6-10-1

*3 个603 京都市北区小山上総町

*4 T680 鳥取市円護寺浜田 $257-2$
ブロック構造を成していることが明らかにされてきた [桂・他 (1987), 茂木・他 (1985a)]. 山崎断層はそうし たブロック境界をなす活断層の一つである (Fig. 1).

山崎断層については, 従来知られていたトレースの東 端 (兵庫県福崎町) [活断層研究会 (1980)] よりさらに東 方へも潜在的に存在し，纭苗市で十万辻断層につながる ことが分かっている [茂木・他(1985b)].一方，西方へ は岡山県勝田町付近まで追跡されている [福井 (1981), 


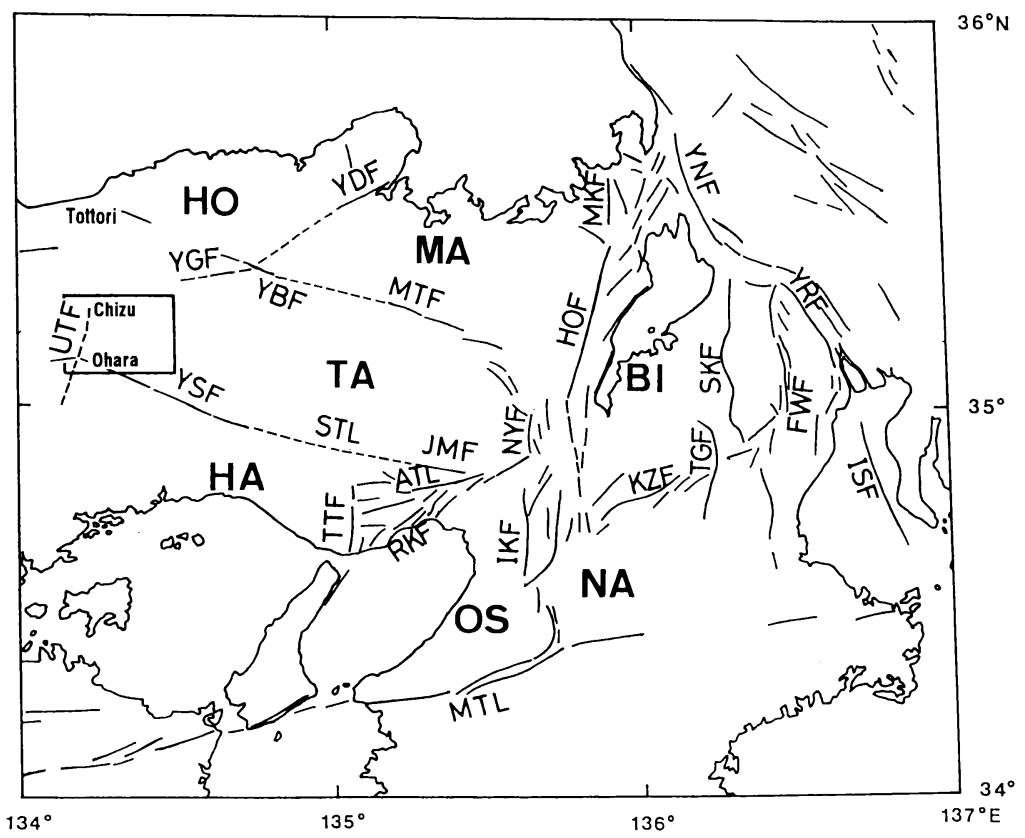

Fig. 1. Surveyed area (in square) and distributions of tectonic blocks and major active faults. Broken line is the estimated part of faults after KAtsura et al. (1987), Mogi et al. (1985a, b), Nishimura et al. (1986) and this study. TA: Tamba, HO: Hokutan, MA: Maizuru, HA: Harima, BI: Biwa-ko, NA: Nara, and OS: Osaka blocks. YSF: Yamasaki, STL: Sanda-Yamasaki, JMF: Jumantsuji, ATL: Arima-Takatsuki, TTF: Takatsukayama, RKF: Gosukebashi, Suwayama and Suma, NYF: Nishiyama, YGF: Yagi, YBF: Yabu, MTF: Mitoke, YDF: Yamada, MKF: Mikata, HOF: Hanaori, IKF: Ikoma, KZF: Kizugawa, TGF: Tongu, SKF: Suzuka, YNF: Yanagase, YRF: Yoro, FWF: Fujiwaradake, ISF: Ise-Bay, MTL: Median Tectonic Line, and UTF: Ute faults.

活断層研究会 (1980), 金属鉱業事業団 (1980)]. しかし, 勝田町豊成より西では, 不確実さが増し, さらには断層 の枝分かれがあったりし，かつ，より西の那岐山断層 [活断層研究会 (1980)] 等との関係も明らかではない [福井 (1981)]. また, 山崎断層の最西端付近を境に東と 西とで活断層の分布状態が大きく異なるのも，よく知ら れている [活断層研究会 (1980), 岡田・安藤 (1979)].

以上の事から, 山崎断層最西端付近には, 近畿北西部 と中国地方を区切る大きな活構造（ブロック境界の役割 をなす）㔹南北走向に存在するのではないかと考えられ る.この地域の微小地震の震央分布 (Fig. 2) を見ると, 山崎断層系の活動が最も顕著であるが，その他に鳥取市 から智頭町付近まで微小地震の震央分布が帯状に延びる こと [尾池 (1976)] が知られている.こうした事実を念 頭に置いて，とくに南北走向のブロック境界をなす活断 層が潜在しているかどうか検証する探査を行った。探査 地域は岡山県北東部の勝田郡勝田町を中心に奈義町, 英 苗郡大原町 - 西粟倉村 - 東粟倉村, 鳥取県八頭郡智頭 町, 兵庫県寒菜郡千種町に及ぶ (Fig. 3).

\section{$\S 2$ 2. ELF-MT 探査}

Electromagnetic Research Group for the Active FAULT (1982) 等に述べられているように，大規模な活 断層では明瞭な低比抵抗帯がみられることが多い。探查 地域では, 多くの断層が存在することが知られている [中国地方土木地質図編纂委員会 (1984)]。これらの断層 やその延長, あるいは未発見の潜在する断層について, ブロック境界の活断層に相当するものを捜すために，ま ず初めに，地域全体にわたり ELF 帯の自然電磁波を用 いたマグネトテルリック (ELF-MT) 探查を実施して, 破 砕帯と推定できる低比抵抗構造を捕捉することにした。

MT 測点は山崎断層系と未知の南北走向断層を捕捉でき るよう配置した (Fig. 3).

ELF-MT 法の測定では, 磁場・電場とも南北 $\left(H_{x} \cdot E_{x}\right)$ 及び東西 $\left(H_{y} \cdot E_{y}\right)$ を同時に 10 分間程度測定した。磁場 センサーはインダクションコイル，電場センサーは銅製 棒電極である. MT 法で得られるテンソルインピーダン スは, 磁場を入力, 電場を出力と考えたときの 2 入力・ 1 出力システムの伝達関数として与えられる [REDDY and RANKIN (1974)]. 従って, データの良悪は, 入出力 


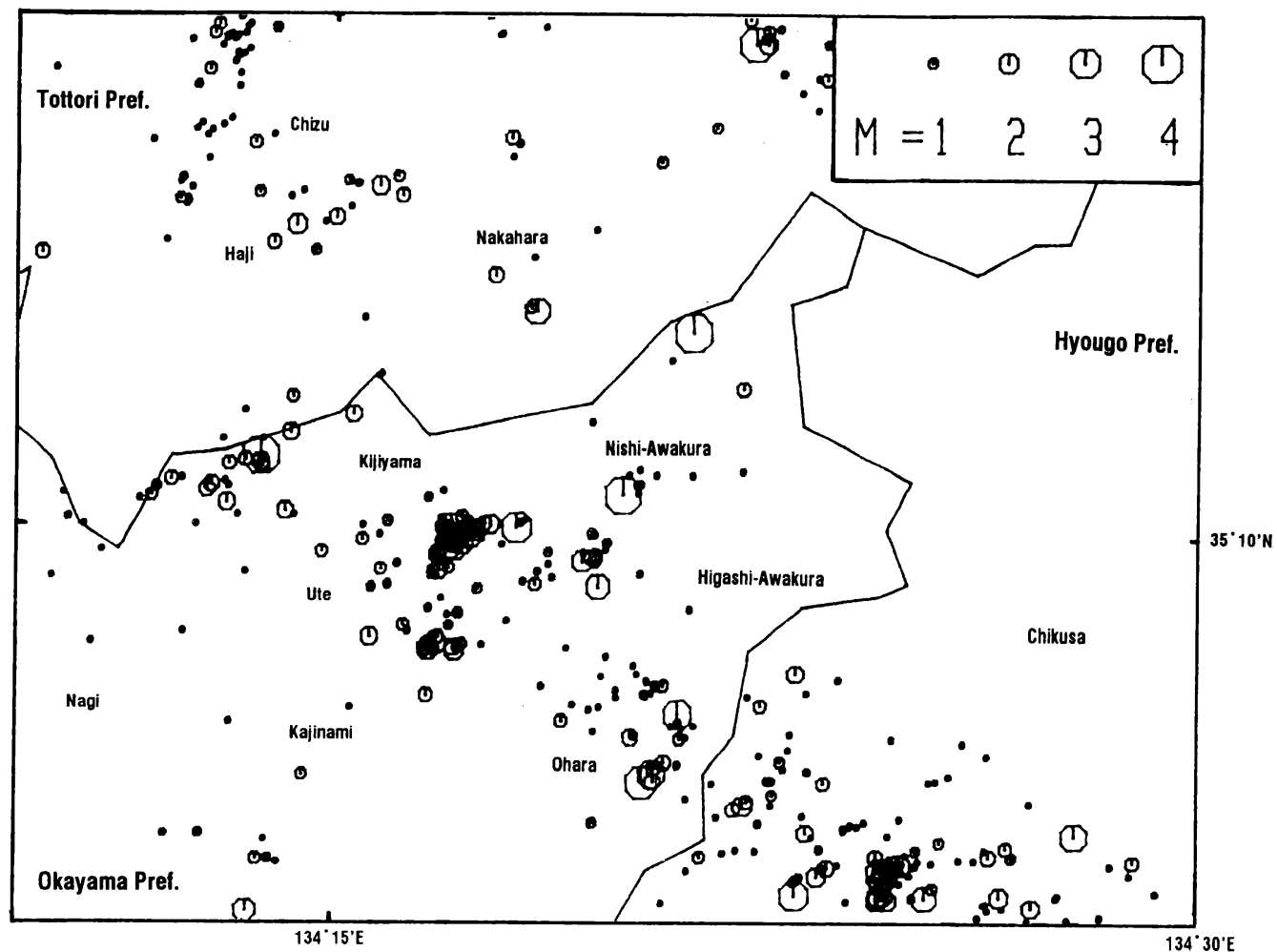

Fig. 2. Seismicitymap around the surveyed area during May 1, 1976-March 31, 1989 (after TotToRI Microearthquake Observatory). Focal depth is shallower than $30 \mathrm{~km}$.

間のコヒーレンシーとして評価できる。記録したデータ は, $125 \mathrm{~Hz}$ でサンプリングし，256 個ごとにFFTをか け，スペクトルを求めた。 こうして求めたスペクトルを 5 回スタッキングしたものについて, 磁場入力 $\left(H_{x}\right.$, $\left.H_{y}\right)$ ・電場出力 $\left(E_{x}\right.$ または $\left.E_{y}\right)$ 間のマルチプルコヒーレン シーの下限と磁場 $\left(H_{x}, H_{y}\right)$ 間のコヒーレンシーの上限を 0.5 としてデータの選別を行った. この条件を満足した あの全てを重好合わせたスペクトルより, テンソルイン ピーダンスを算出した [VozoFF (1972)]. さらに, 主軸変 換により，地下構造が二次元的であるという前提のもと に, インピーダンステンソルの主軸方向を求めた. また, スキューが 0.5 以下のもののみを採用することとした

その結果は, シューマン共振周波数のうち $7.8 \mathrm{~Hz}$ の あのを例として Fig. 4 に示した. 図では, 主軸方向の見 掛比抵抗値を線の長さで表した。主軸方向は長軸・短軸 で示されている. 活断層のような破砕帯に相当する低比 抵抗帯が二次元的に延びているときは, そのような構造 の上および近傍で見掛比抵抗は異方性が顕著になる。低 比抵抗帯の上では長軸はその層の延びの方向に平行に, その両側近傍では長軸はその層の延びの方向に直角に向 く、こうしたことをもとに破砕帯の位置を推定すれば,
最も顕著なむのは梶並川に沿った南北走向の構造であろ う. B12 から B17 にかけての測点で, 南北方向に延びる 顕著な長軸により, 低比抵抗帯が推定できる。 その他に は，木地山から方手峠にかけての北東-南西走向の構造 が B6〜B9 測点より推察される. また，木地山峠付近に も西北西一東南東走向の構造が A19 A22 測点より示唆 される.

活断層地図 [活断層研究会 (1980)］と比較してみれ ば，木地山から右手峠にかけてのリニアメントが北東一 南西走向の構造に該当する. 西粟倉村坂根から塩谷にか けて活断層であると推定される東西走向のリニアメント （確実度 I）が記されている[活断層研究会 (1980)］が, Fig. 4 を見る限り検知し得ていない. わずかに塩谷新田 あたりの南北に延びた A17〜A19 测点の長軸の向きが 東西走向の構造の縁を示しているかとも見える. また, 木地山峠を通る西北西-東南東走向の構造は, 西粟倉村 筏津・知社から木地山峠に延びる微小地震の分布（Fig. 2 参照）に相当するかと考えられる.この構造は山崎断 層の主断層に平行した断層と見なすことができ，活断層 地図では活断層の疑いのあるリニアメント（確実度 III） とされている[活断層研究会 (1980)]．Fig. 2 では木地 


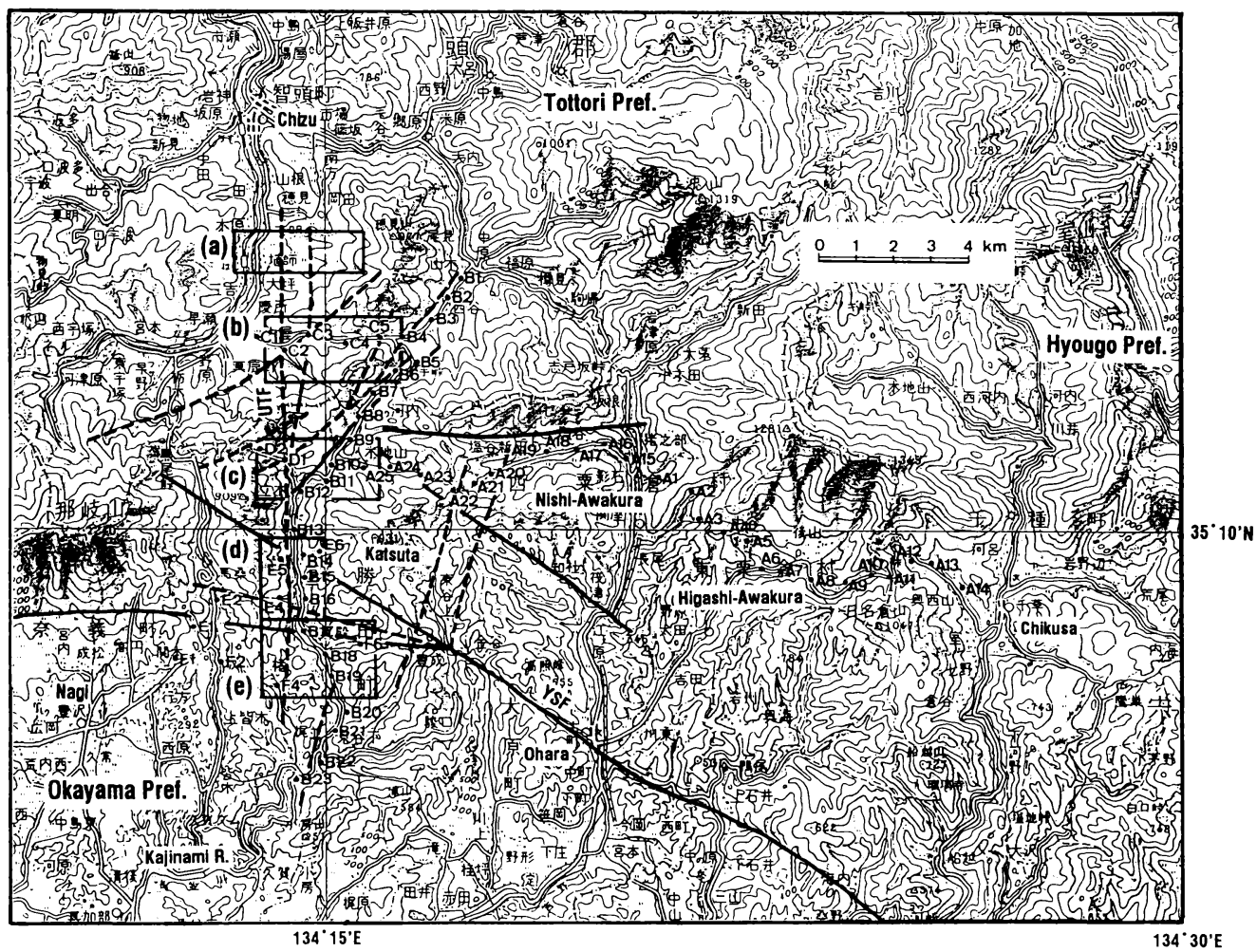

Fig. 3. Map showing the surveyed area. Solid circles are the ELF-MT sites. Squares of (a) to (e) are the $\gamma$-ray survey areas. Solid and broken (estimated in this study) lines are traces of the faults. YSF: Yamasaki, and UTF: Ute faults.

山峠南側に微小地震の多発する巣があるが，これはこの 構造（山崎断層系）と木地山峠から南南西に延びるリニ アメント（地形図から読み取れる）との交点に位置する. ただし, 微小地震は $30 \mathrm{~km} よ り$ 浅いが, 断層構造は未詳 である。

梶並川に沿った南北の構造は,これまで知られていな かったが, 勝田町のこの地域では, 山崎断層系の延長上 にある断層がいくつか推定されていた．Fig. 4 の見掛比 抵抗分布を見る限り, 南北に延びた長軸方向が数点にわ たり連続するので, 山崎断層系の西北西-東南東走向の 構造の縁を捉えているとするよりも, 南北方向に低比抵 抗帯が延びていると考えられる．地形図から読み取れる 梶並川に沿ったリニアメントは, 川の右岸 (西側) で顕 著である.このことより, 梶並川に沿って南北走向の断 層が潜在的に存在し，かつ主破砕部は川の西側らしいと 推定できる，ただし，断層の露出が悪いため, 現在のと ころ,どういう動きをした断首であるかは未確認であ る.この構造を右手断層と仮に呼ぶことにする.

\section{§ 3. $\gamma$ 線 探 查}

ELF-MT 探査により新たに推定された右手断首が通 る位置を明確にするため， $\gamma$ 線シンチレーションサーベ イメーターを用いた $\gamma$ 線探査を行った，併せて山崎断層 系との関係をも推定できるよう測線を配置した， $\gamma$ 線探 查の測線位置はFig. 3 に, より詳細な測点位置図と $\gamma$ 線 線量率プロファイルを Fig. 5 に示す. $\gamma$ 線の測定は, 各 測点ごとにサーベイメーターのディテクターを挿入でき る穴を約 $10 \mathrm{~cm}$ の深さであけ，そこで 5 秒ごとに 12 回 值を読み取り, 最大・最小の 2 值を除いた 10 回の值の 平均をその測点の $\gamma$ 線線量率とするという方法によった [例えば，桂・他 (1987)]。測点間隔は測線により $15 \mathrm{~m}$ または $20 \mathrm{~m}$ とした。

測定結果 (Fig. 5) は，その地域の岩相を反映している ととあに，断首による割れ目が地表近くにあれば， $\gamma$ 線 線量率のピークが現れることが多い．Fig. 5 のうち(a) 圼師・(b) 大屋-大師峠・(c) 立木一木地山の 3 測線は, ほ ぼ全線にわたり花岡岩地帯であり [山田(1966)], とく に (c) 立木一木地山測線は露岩地帯が多く, 連続して $\gamma$ 線 線量率のプラトーが見られる所がそれに該当する. (d)唐 


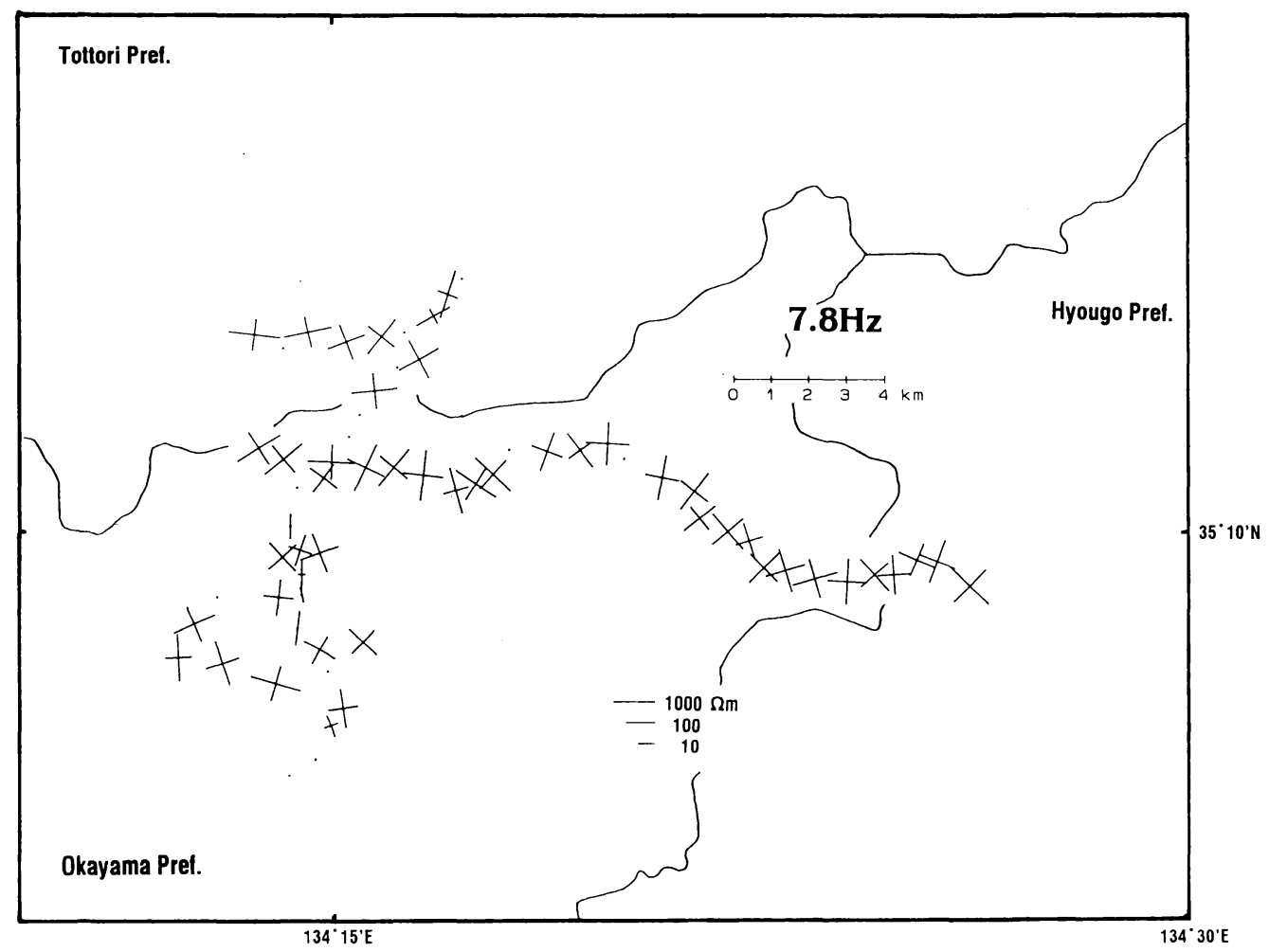

Fig. 4. Principal axis directions of impedance tensor estimated from ELF-MT survey for $7.8 \mathrm{~Hz}$. Length of axis is apparent resistivity value.

手一塩木測線はだいたい安山岩地帯とされているが, 測 点 100 前後と 75 前後のプラトーは流紋岩質岩の露出に よる [河合 (1958), 金属鉱業事業団 (1980)]。(e) 楮 谷測線は三郡変成帯の千枚岩ないし片岩等の分布地域で あるが，その東端（測点 190 以降）のプラトーは流紋岩 地帯になっている[神戸・広川 (1963), 河合 (1958), 金 属鉱業事業団 (1980)].

Fig. 5 には $\gamma$ 線線量率のピークのうち断首による可能 性のあるものに矢印を付けた。これらのうち岩相による 特異な影響を勘案し, さらに地形リニアメントを考慮し て断層と推定し得る所のみを残した。そうして ELF-MT 法による結果も合わせた上で，とくに連続性 のよい推定断層線を Fig. 5 に示した. 破線部は断層の疑 いがあるが連続性の低いあのである.さらに, Fig. 3 に は断層の推定位置をまとめた。

\section{§4. 近裁北西部のブロック境界}

近畿地方北西部地域のブロック構造や, 微小地震の震 央分布によると, 山崎断層最西端部にブロックの境界之 なるような活断層の存在が想定されていた。 今回の探査 の結果, 山崎断層系の主断層は, 大原町古町から勝田町
豊成・唐手塩木を経て奈義町の黒尾峠南方へ追跡できる ことが確認された。このラインは「日本の活断層」[活断 層研究会 (1980)］に記載されていたものに等しい，その 他に山崎断層主断層は，豊成以西で枝分かれし，その分 枝の 2 本が今回新たに推定できた。 また，西粟倉村筏 津・知社から木地山峠に至る構造は, 山崎断層系の副断 層と推定でき，かつ地震活動からみて主断層同様活動的 であると考えられる. その南東方はリニアメントなどか ら兵庫県山崎町ないし安富町まで追跡できる. 山崎断層系以外に今回新たに見いだした吝手断層が, この地域の主要な活構造と考えられる，右手断層は，見 掛比抵抗分布 (Fig. 4) から見て低比抵抗帯が南北走向で 発達していると推定される. 山崎断層系のように微小地 震が発生していないが (Fig. 2 参照), このことは, 右手 断層は活動的ではなく，現在は活動が終息したか休止期 にあることを意味する．右手断層と山崎断層の会合部 (Fig. 5(d)) の地形からは, 山崎断層の活動の方が新しい 之推定できる．断層活動がおそらく終息したにも拘らず 今屯低比抵抗帯が顕著なのは, 右手断層の最終活動時期 がそれほど古くはないためと考えられる.さらに，右手 断層の低い見掛比抵抗值を見ても，山崎断層之の会合部 

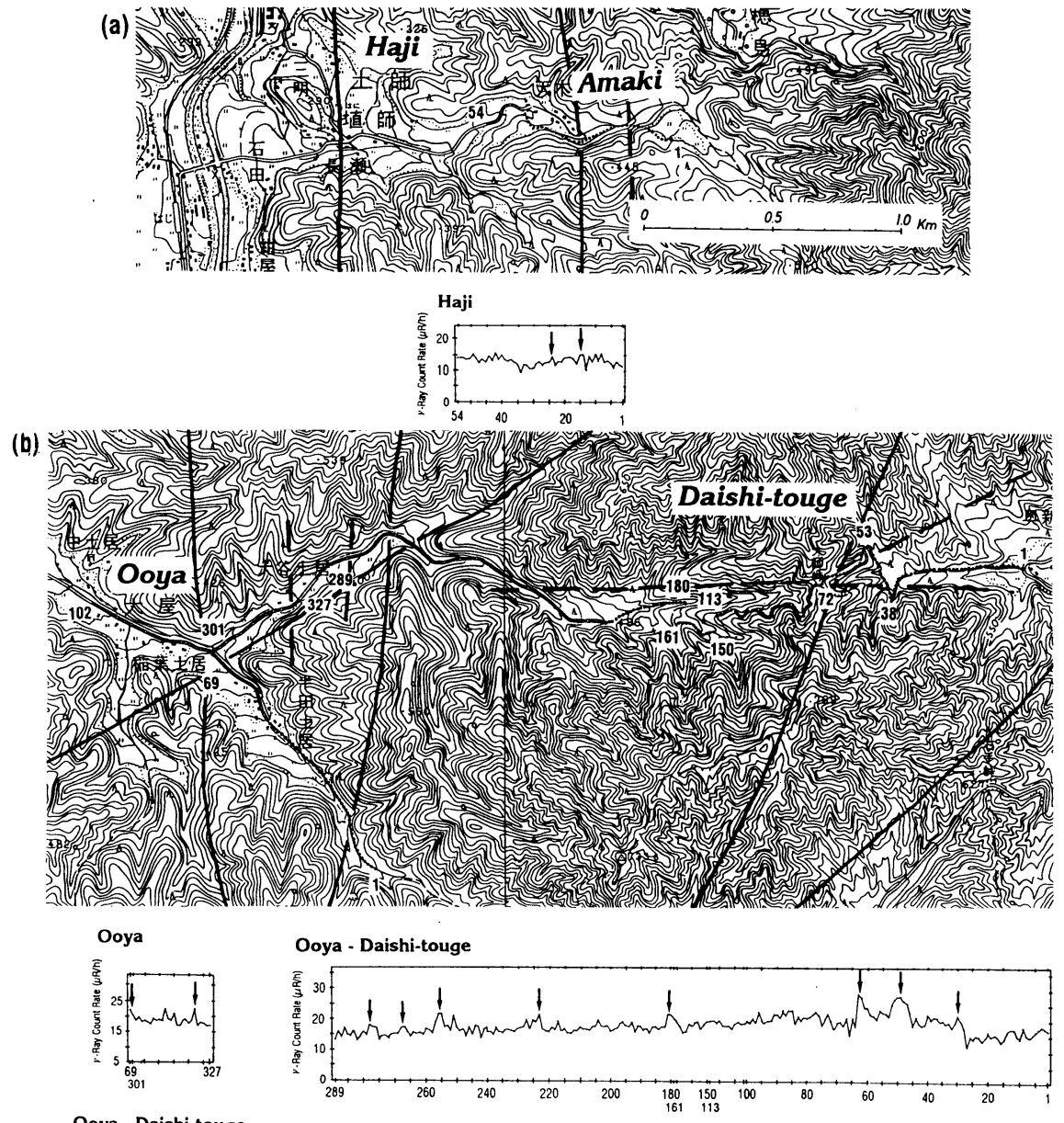

Ooya - Daishi-touge

(c)

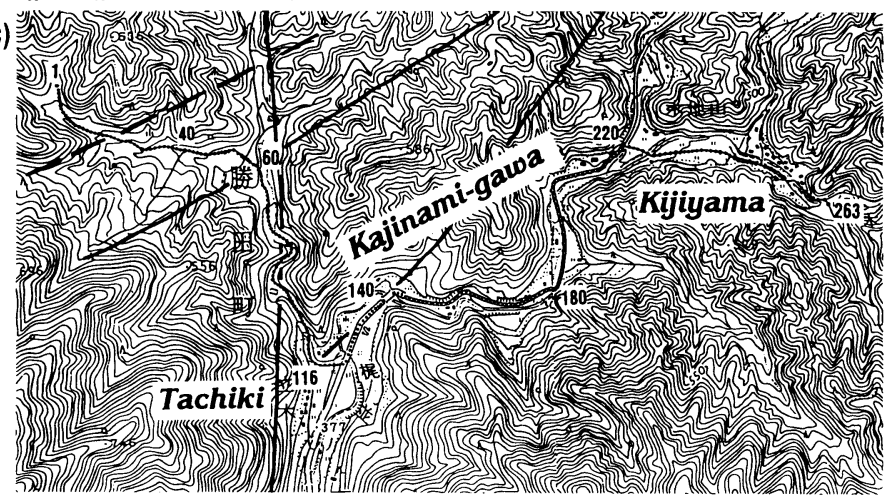

Tachiki - Kijiyama

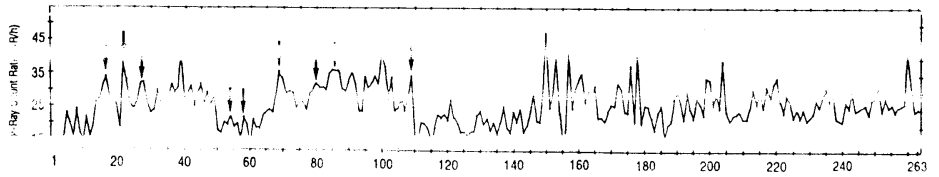


(d)
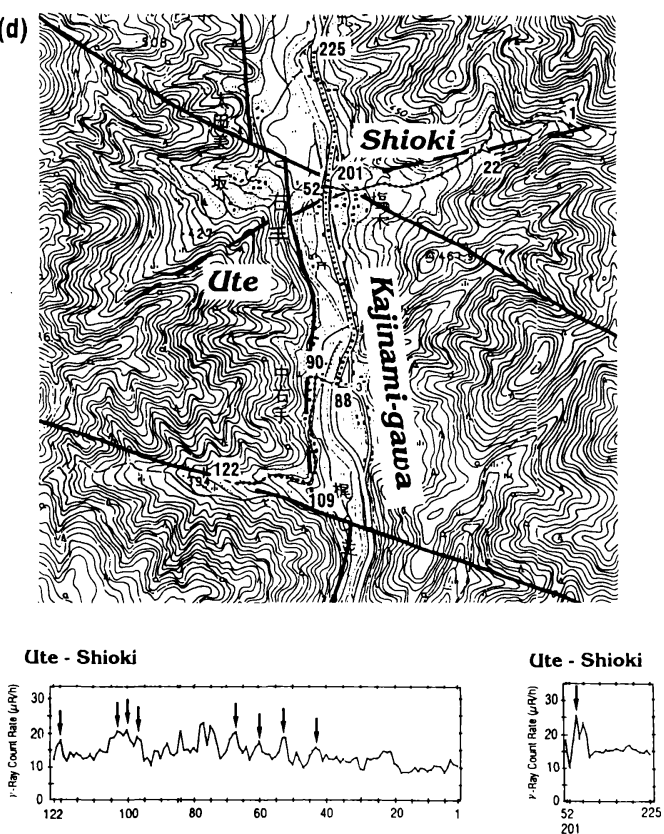

(e)

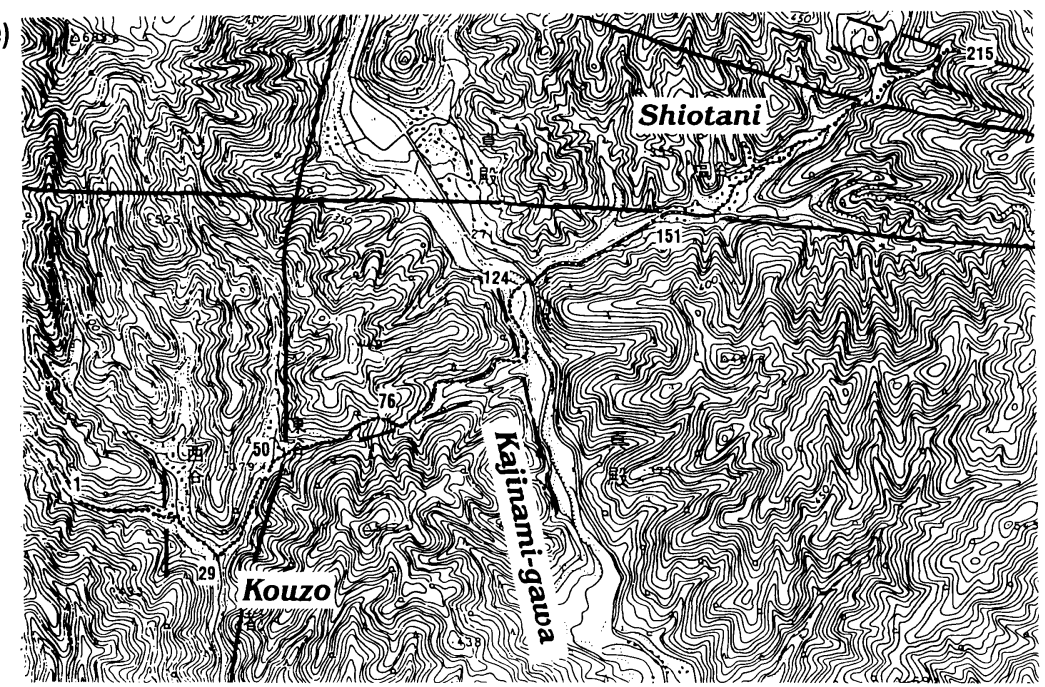

Kouzo - Shiotani

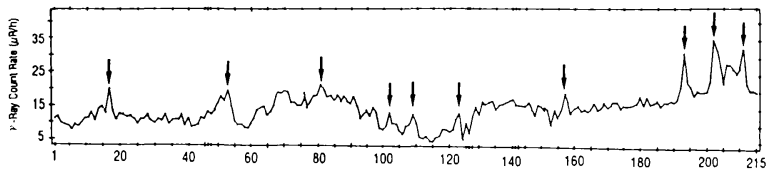

Fig. 5. Profiles of $\gamma$-ray count rate and maps of the survey points. Allows in the profiles indicate the possible positions of fault lines. Solid and broken (low rank of continuity) lines in the maps show the estimated fault traces. (a) Haji, (b) Ooya-Daishi Pass, (c) Tachiki-Kijiyama, (d) Ute-Shioki, and (e) Kouzo-Shiotani lines.

がとくに低いように見受けられる．右手断層の破砕帯 が，会合部以外ではしだいに瘉着されつつあるのに対 し, 会合部では山崎断層の活動に伴い今も破砕が繰り返
されて低比抵抗状態が保たれていると考えられる。

山崎断層系は，地形の上でもそれ以北と以南とで明瞭 な境界をなし，かつ地震が集中する [MINO (1984)]。さ 
らに，その東方延長は十万辻断層を経て有馬一高柣構造 線に届くと推定できる [茂木・他 (1985b)]. 山崎断層の ような長大な活構造は, 地殼上層部を区切る境界をなす と考え[茂木・他 (1985a)]，そうして区切られたテクト ニクス上の単元をブロックと呼んだ [桂・他(1987)].

こうしたブロックやブロック境界をなす活断首について は，前に暫定的に述べた [桂・他(1987)].それにおいて は, 山崎断層の最西端部付近に，山崎・有馬一高柣・三 峠・養父一八木断層等により囲まれたいわゆる丹波ブ ロックの西を区切る構造があることを予想した。

右手断層は, 南は勝田町梶並あたりまで, 北は智頭町 圭師あたりまで，地形上から追跡できよう。より北方へ は，鳥取から智頭へかけて帯状に亚ぶ微小地震の分布 [尾池 (1976)] へつながると予想される.ただし，リニア メントは智頭以北では明瞭でない，活断層の分布パター ンが（とくに中国山地南側では）この付近を境に大きく 変わることは以前から知られていたが [活断屏研究会 (1980), 岡田・安藤 (1979)], そうした地域差を際だた せる境界はやはりブロック境界である可能性が高い，い わゆる丹波ブロック［桂・他(1987)］の西側境界の候補 として右手断層は位置づけられる．右手断層の運動様 式, 活動度, 最終活動時期, 破砕帯の幅・深さ等, 詳し いことは今後の調查に待たねばならない.

\section{§5.まとめ}

山崎断層系の西端部付近一帯で ELF-MT 探查と $\gamma$ 線 探査を行った。その結果, 山崎断層系は最西端部におい て, 主断層の他に枝分かれした 2 本の断層之, 主断層に 平行した副断層が推定できた。 また，山崎断層系の末端 では，山崎断層に斜交した低い見掛比抵抗を示す南北走 向の構造が梶並川沿いに推定される。これを方手断層と 仮称する. 右手断層は，現在は活動的でないが，その周 辺に南北性の大きな破砕構造がないこと，この付近を境 に東西で活断層の分布パターンが大きく変わること，ま た，その延長が智頭以北鳥取までの微小地震活動の帯状 分布に続きそうであることなどから，近畿と中国地方を 分かつブロック境界である可能性が高い。

\section{文献}

中国地方土木地質図編纂委員会，1984，中国地方土木地 質図 $(1 / 20$ 万) 及び解説書, 中国地方土木地質図編纂 委員会, $412 \mathrm{pp}$.

Electromagnetic Research Group for the Active FAULT, 1982, Low electrical resistivity along an active fault, the Yamasaki fault, J. Geomag. Geoelectr., 34, 103-127.

福井謙三, 1981, 山崎断層系の変位地形, 地理評, 54 , 196-213.

神戸信和・広川 治, 1963,5 万分の 1 地質龱幅「佐用」 及び同説明書, 地質調査所, $29 \mathrm{pp}$.

活断層研究会, 1980 , 日本の活断層, 東京大学出版会, $238-239$.

桂 郁雄・西村 進・Edy M. ARSADI ・赤松 信・松田 高明, 1987 , 近畿地方北西部地域の活構造 (5)一八木 断層, 山田断層の検討と近畿北西部のブロック構造 一, 地震 $2,40,561-573$.

河合正虎， $1958 ， 5$ 万分の 1 地質図幅「津山東部」及び 同説明書，地質調查所， $63 \mathrm{pp}$.

金属鉱業事業団，1980，昭和 54 年度広域調査報告書， 津山地域, 付図一津山地域地質図, 通商産業省資源工 ネルギー庁, $132 \mathrm{pp}$.

Mino, K., 1984, On a formation mechanism of topography and its relation to earthquake occurrence in southwest Japan, Bull. Disas. Prev. Res. Inst., Kyoto Univ., 34, 129-167.

茂木 透・見野和夫・西村 進, $1985 \mathrm{a}$, 近畿地方北西 部地域の活構造 (3)一八木・養父, 三峠断層地域一, 地 震 $2,38,577-585$.

茂木 透・西村 進・見野和夫 - 貞広太郎, 1985b，近 畿北西部地域の活構造 (1)一山崎断層東方延長地域一, 地震 2, 38, 57-66.

西村 進・茂木 透・赤松 信・松田高明, 1986, 近畿 地方北西部地域の活構造 (4)一山田断層の西方延長地 域一, 地震 $2,38,371-380$.

尾池和夫, 1976 , 微小地震の時空分布之活断層, 地質学 論集, 12, 59-73.

岡田篤正・安藤雅孝, 1979 , 日本の活動層之地震, 科 学, 49, 158-169.

ReDDY, I. K. and D. RANKIN, 1974, Coherence functions for magnetotelluric anaysis, Geophysics, 39, $312-320$.

Vozoff, K., 1972, The magnetotelluric method in the exploration of sedimentary basins, Geophysics, 37, 98-141.

山田直利, 1966,5 万分の 1 地質図幅「智頭」及び同説 明書, 地質調查所, $69 \mathrm{pp}$. 